\title{
Tracheobronchial Lymph Node
}

National Cancer Institute

\section{Source}

National Cancer Institute. Tracheobronchial Lymph Node. NCI Thesaurus. Code C77651.

A lymph node located near the bifurcation of the trachea. 